\title{
ANALISIS OPERATIONAL EFFICIENCY RATIO \\ DAN COST EFFICIENCY RATIO TERHADAP NET PROFIT MARGIN \\ BANK MANDIRI TBK
}

\author{
Lite \\ Email : lite@gmail.com
}

STIE Palangka Raya

\begin{abstract}
This research aims to examine the influence of operational efficiency ratio (OER) and cost efficiency ratio (CER) toward net profit margin (NPM) at Bank Mandiri,Tbk. The back ground of this research done is due to the bank's low rate in obtaining NPM.

Based on the classical assumption test's result, the two independent variables chosen in this research are normally distributed with no disorder found. According to the correlationtest's result, it is found that OER correlates to the NPM as high as $95.6 \%$ while the CER correlates to the NPM as high as $92.7 \%$. In addition, based on the R-square test's result, it is found that both independent variables are high as $91.6 \%$ for each change in the NPM.

Based on the F test, it is found that both independent variables, including OER \& CER have significant influence toward NPM simultaneously, in which the P-value less than 0.05 (5\%).

The t-test's result, however, shows that OER has negative and effect toward NPM partially, while the CER has the positive effect and the two variables have no significant effect partially. Therefore, the step wise test is required to be done in order to get which variable that issignificant partially. And this results that OER has significant and negative effect toward NPM partially with P-value less than $0.05(5 \%)$ and $\mathrm{t}$-calculated value $[-8.030]>\mathrm{t}$-table $[1.860]$.
\end{abstract}

Keyword : BOPO, CER, NPM

Jurnal Komunikasi Bisnis dan Manajemen

Vol. 5 No. 2 Juli 2018 


\section{PENDAHULUAN}

Sektor perbankan memang merupakan sector yang paling cepat terpukul jika keadaan ekonomi tidak stabil. Industri perbankan merupakan industry yang sarat dengan resiko, terutama karena melibatkan uang masyarakat dan diputar dalam berbagai bentuk investasi, seperti pemberian kredit, pembelian surat-surat berharga dan penanaman dana lainnya.

Perkembangan perolehan laba pada sektor perbankan beberapa tahun ini tak lepas dari membaiknya fungsi intermediasi perbankan nasional dan meningkatnya efisiensi pada biaya-biaya yang dikeluarkan oleh bank itu sendiri. Dengan kata lain, bank yang dapat menekan biaya dan mengoptimalkan kinerja operasionalnya akan mampu mendapatkan perolehan laba yang besar.

Tujuan dari penelitian ini adalah (a) Untuk mengetahui pengaruh operational efficiency ratio dan cost efficiency ratio terhadap netprofit margin pada Bank Mandiri secarasimultan. (b) Untuk mengetahui pengaruh operational efficiency ratio dan cost efficiency ratio terhadap netprofit margin pada Bank Mandiri secara parsial.

\section{TINJAUAN PUSTAKA}

\section{Laporan Keuangan Bank}

Laporan keuangan bank melaporkan kinerja keuangan masa lalu dan menunjukkan posisi keuangan terakhir. Pengguna laporan keuangan bank membutuhkan informasi yang dapat dipahami, relevan, handal dan dapat dibandingkan dalam mengevaluasi posisi keuangan dan kinerja bank serta berguna dalam pengambilan keputusan ekonomi (IAI,2004). Salah satu 
informasi yang diperlukan investor adalah kinerja bank dalam menghasilkan laba.

Dari laporan keuangan bank dapat diketahui rasio-rasio keuangan perbankan. Dan dengan menggunakan rasio keuangan, investor dapat mengetahui kinerja suatu bank. Hal ini sesuai dengan pernyataan Muljono (1999) bahwa perbandingan dalam bentuk rasio menghasilkan angka yang lebih obyektif, karena pengukuran kinerja tersebut lebih dapat dibandingkan dengan bank-bank yang lain ataupun dengan periode sebelumnya.

Laporan keuangan bank umumnya dipublikasikan dalam berbagai bentuk sesuai dengan waktu terbitnya, laporan keuangan bank berisi empat laporan utama (a) Neraca (Balancesheet) (b) Laporan laba-rugi (Incomestatement) (c) Laporan perubahan Ekuitas (Change of equity statement) (d) Laporan arus kas (Cash flow statement). Penelitian ini berfokus terhadap efisiensi biaya operasional terhadap perolehan net profit margin, maka jenis laporan keuangan yang digunakan dalam penelitian ini adalah laporan laba rugi atau income statement.

\section{Rentabilitas/Profitabilitas}

Rentabilitas suatu perusahaan menunjukkan perbandingan antara laba dengan modal atau biaya yang digunakan untuk menghasilkan laba tersebut.

Dengankatalain,rentabilitasmerupakankemampuansuatu perusahaanuntuk menghasilkanlabaselama periodetertentu(Riyanto,2001).

Menurut Silvina (2009) rentabilitas mempunyai sinonim dengan rate of retum, earning power, dan profitability. Yang dimaksud rentabilitas yaitu kemampuan perusahaan untuk memperoleh laba. Kalau laba atau profit adalah jumlahnya, maka rentabilitas adalah kemampuan untuk memperoleh jumlah tersebut. Sedangkan bagi sector perbankan, rentabilitas 
adalah kemampuan bank dalam menghasilkan profit (laba) dari operasi bank (Abdullah,2003).

Rasio rentabilitas mampu mengukur keberhasilan manajemen sebagaimana ditunjukkan oleh laba yang dihasilkan dari penjualan. Pertumbuhan rentabilitas ini ditandai dengan perubahan profit margin on sales. Dengan tingkat profitabilitas yang tinggi berarti perusahaan akan beroperasi pada tingkat biaya rendah yang akhirnya akan menghasilkan laba yang tinggi (Ningsih, 2008).

Salah satu bagian dari analisis rasio keuangan, analisis rasio rentabilitas (profitabilitas) juga didasarkan pada data keuangan histroris yang tujuan utamanya adalah member suatu indikasi kinerja perusahaan dimasa yang akan datang.

Informasi hasil kinerja perusahaan diperlukan agar investor sebagai pihak yang berkepentingan serta masyarakat umum dapat mengetahui tingkat kesehatan suatu perusahaan.

\section{Operational Efficiency Ratio (OER)}

Operational efficiency ratio atau, dalam bahasa Indonesia, lebih dikenal sebagai rasio BOPO merupakan rasio yang menunjukkan besaran perbandingan antara beban atau biaya operasional terhadap pendapatan operasional suatu perusahaan pada periode tertentu (Riyadi, 2004). Operational efficiency ratio telah menjadi salah satu rasio yang perubahan nilainya sangat diperhatikan terutama bagi sector perbankan mengingat salah satu criteria penentuan tingkat kesehatan bank oleh Bank Indonesia adalah besaran rasio ini.

Bank yang nilai Rasio BOPO tinggi menunjukkan bahwa bank tersebut tidak beroperasi dengan efisien karena tingginya nilai dari rasio ini memperlihatkan besarnya jumlah biaya operasional yang harus dikeluarkan 
oleh pihak bank untuk memperoleh pendapatan operasional. Di samping itu, jumlah biaya operasional yang besar akan memperkecil jumlah laba yang akan diperoleh karena biaya atau beban operasional bertindak sebagai faktor pengurang dalam laporan laba rugi. Nilai rasio BOPO yang ideal berada antara 50-75\% sesuai dengan ketentuan Bank Indonesia.

Berdasarkan Surat Edaran Bank Indonesia No.6/23/DPNP tanggal 31 Mei 2004, kategori peringkat yang akan diperoleh bank dari besaran nilai operational efficiency ratio yang dimiliki adalah sebagai berikut:

Tabel 1

\section{Peringkat bank berdasarkan operational efficiency ratio (BOPO)}

\begin{tabular}{|c|l|l|}
\hline Peringkat & \multicolumn{1}{|c|}{ Predikat } & \multicolumn{1}{c|}{ BesarannilaiOER/BOPO } \\
\hline 1 & SangatSehat & $50-75 \%$ \\
\hline 2 & Sehat & $76-93 \%$ \\
\hline 3 & CukupSehat & $94-96 \%$ \\
\hline 4 & KurangSehat & $96-100 \%$ \\
\hline 5 & TidakSehat & $>100 \%$ \\
\hline
\end{tabular}

Sumber: SE BI No.6/23/DPNP tanggal 31 Mei 2004.

\section{Cost Efficiency Ratio (CER)}

Cost efficiency ratio merupakan rasio yang digunakan untuk mengukur seberapa besar biaya non-bunga yang dikeluarkan suatu bank demi menghasilkan pendapatan bunga bersih dan pendapatan lainnya selain pendapatan bunga (Timothy \& Scott, 2000).

Biaya non bunga atau non-interest expense yang biasa disebut sebagai overhead cost terdiri dari penyisihan kerugian atas aktiva produktif dan nonproduktif, biaya tenaga kerja, tunjangan karyawan serta biaya administrasi \& umum (biaya listrik, telepon, sewa gedung, kendaraan, pemeliharaan $\mathrm{dsb}$ ), sedangkan pendapatan non-bunga terdiri dari pendapatan komisi dan provisi non- kredit; pendapatan transfer, penolakan cek dan intercity; 
keuntungan transaksi valuta asing dan pendapatan jasa bank lainnya di luar pendapatan yang berhubungan dengan pemberian kredit. Pendapatan non bunga sering disebut sebagai fee based income.

Alasan suatu bank menggunakan rasio CER sebagai indikator efisiensi karena biaya yang digunakan dalam menghitung CER sebagian besar terdiri dari biaya variabel (variable cost) yang tak lain merupakan jenis biaya yang dapat ditekan, seperti biaya umum, administrasi dan tenaga kerja. Dan jika suatu bank mampu memperoleh pendapatan dalam jumlah besar dengan biaya yang relatif kecil, maka dapat dikatakan bahwa bank tersebut mampu untuk mengoptimalkan segala sumberdaya yang dimilikinya (Riyadi, 2004). Besaran nilai rasio ini menurut Timothy \& Scott (2000) untuk predikat sangat baik adalah 50-55\% dan semakin besar nilainya, semakin tidak efisien.

\section{Net Profit Margin (NPM)}

NPM menunjukkan perbandingan antara laba bersih dengan penjualan (Hanafi dan Halim, 2005). Rasio ini digunakan untuk menghitung sejauh mana kemampuan bank yang bersangkutan dalam menghasilkan laba bersih (net income) ditinjau dari sudut total penjualannya. NPM mengacu kepada pendapatan operasional bank yang terutama berasal dari kegiatan pemberian kredit yang dalam prakteknya memiliki berbagai risiko kredit (kredit bermasalah dan kredit macet), bunga (spread), kurs valas (jika kredit diberikan dalam valas).

Semakin tinggi tingkat rasio net profit margin bank yang bersangkutan menunjukkan hasil yang semakin baik, demikian sebaliknya (Muljono, 1999). Selain itu, rasio NPM juga memiliki hubungan positif dengan laba bersih, dimana semakin meningkat nilai rasio ini, semakin baik peningkatan perolehan laba bersih suatubank, demikian juga sebaliknya. 


\section{Hubungan antara Operational Efficiency Ratio (OER) \& Cost Efficiency Ratio (CER) dengan Net Profit Margin (NPM)}

Baik variabel dependen (NPM) maupun variabel independen (OER\&CER) dalam penelitian ini merupakan bagian dari laporan laba-rugi. NPM dihitung berdasarkan hasil bagi antara laba bersih dan total penjualan, artinya semakin besar laba suatu bank, semakin tinggi nilai NPM bank tersebut. Dilain pihak, OER \& CER merupakan variabel yang mencerminkan seberapa besar biaya-biaya yang dikeluarkan oleh pihak bank dalam melaksanakan kegiatan operasional.

Jika OER menunjukkan seberapa efektif pihak bank dalam menekan seluruh biaya operasional, maka CERmenunjukkan seberapa efektif pihak bank dalam menekan biaya overhead. Bedanya, nilai OER telah memasukkan biaya bunga dalam perhitungan sedangkan CER tidak memasukkan biaya bunga dalam perhitungan.

Dengan kata lain, OER bertujuan untuk memperlihatkan sejauhmana pihak bank mampu menekan biaya yang berkaitan dengan fungsi utama bank, yakni seluruh biaya yang timbul akibat dari kegiatan menghimpun dan menyalurkan dana, sedangkan CER hanya menunjukkan biaya yang timbul akibat dari penggunaan sumber daya dan alat pendukung bagi kegiatan operasional.

Menyangkut masalah biaya, OER dan CER memiliki pengaruh negative terhadap NPM karena dalam laporan laba rugi, biaya merupakan faktor pengurang. Oleh karena itu, semakin tinggi biaya-biaya operasional bank, semakin besar faktor pengurang dalam laporan laba rugi. Hal ini akan mengurangi jumlah laba bersih yang selanjutnya berakibat terhadap perolehan NPM. Dengan kata lain, semakin besar OER \& CER, semakin rendah NPM yang akan diperoleh. 


\section{Hipotesis}

(a) Diduga OER \& CER secara simultan berpengaruh signifikan terhadap NPM (b) Diduga OER \& CER secara parsial berpengaruh negative dan signifikan terhadap NPM.

\section{METODOLOGI PENELITIAN}

Penelitian ini berbentuk penelitian deskriptif kuantitatif yaitu penelitian yang mengungkap besar atau kecilnya suatu pengaruh atau hubungan antar variabel yang dinyatakan dalam angka-angka.

Jenis data yang digunakan dalam penelitian ini adalah data sekunder, yakni laporan keuangan BankMandiri, Tbk.

Teknik pengumpulan data yang digunakan dalam penelitian ini adalah metode pengumpulan data historis (documentary-historical). Variabel terikat dalam penelitianini adalah net profit margin (NPM) yang diberi symbol Y, dengan indikator net income dan net sales.

Statistik untuk menguji hipotesis dalam penelitian ini menggunakan metode regresi linier berganda dengan rumus: $\mathrm{Y}=\mathrm{a}+\mathrm{b} 1, \mathrm{~b} 2 \times 1 \times 2 \mathrm{Xi}$

Dimana :

$\begin{array}{lll}\mathrm{Y} & = & \text { Net Profit Margin(dalam persentase) } \\ \mathrm{a} & = & \text { Konstanta persamaan regresi } \\ \mathrm{b} 1, \mathrm{~b} 2, & & \text { Koefisienregresi } \\ \mathrm{x} 1 \quad= & \text { Operational efficiency Ratio (dalam persentase) } \\ \mathrm{x} 2 & = & \text { Cost Efficiency Ratio (dalam persentase) } \\ \mathrm{e} & = & \text { Standar error }\end{array}$

\section{HASIL PENELITIAN}

\section{Hasil Uji Korelasi}

Untuk mengetahui hubungan antara operational efficiency ratio (rasio $\mathrm{BOPO}$ ) dan cost efficiency ratio (CER) terhadap net profit margin (NPM) pada 
Bank Mandiri, Tbk digunakan pengujian korelasi. Uji korelasi merupakan sebuah analisis yang digunakan untuk menyelidiki hubungan antar dua variabel. Hasil uji korelasi dapat dilihat pada tabel berikut ini:

Tabel 2

Hasil Uji Korelasi

Correlations

\begin{tabular}{|c|c|c|c|c|}
\hline & & NPM & OER(BOPO) & CER \\
\hline \multirow[t]{3}{*}{ Pearson Correlation } & & 1.000 & -.956 & -.927 \\
\hline & \multirow[t]{2}{*}{ OER (BOPO) CER } & -.956 & 1.000 & .576 \\
\hline & & -.927 & .576 & 1.000 \\
\hline \multirow[t]{2}{*}{ Sig.(1-tailed) } & NPM & & .000 & .000 \\
\hline & OER (BOPO) CER & .000 & & .060 \\
\hline \multirow[t]{4}{*}{$\mathrm{N}$} & NPM & .000 & .060 & . \\
\hline & \multirow[t]{3}{*}{ OER (BOPO) CER } & 8 & 8 & 8 \\
\hline & & 8 & 8 & 8 \\
\hline & & 8 & 8 & 8 \\
\hline
\end{tabular}

\section{Sumber: Data Olahan (2018)}

Untuk menafsirkan angka korelasi antar variabel menurut Pratisto (2009) digunakan kriteriasebagai berikut:

0- $25 \% \quad$ : korelasi sangat lemah (dianggap tidak ada)

26-50\% : korelasi cukup

51-75\% : korelasi kuat

76-100\% : : korelasi sangat kuat

Berdasarkan data yang diperoleh dari SPSS 25 dapat ditafsirkan hubungan antara variabel-variabel adalah sebagai berikut (a) Terdapat korelasi negatif yang sangat kuat antara operational efficiency ratio (Rasio BOPO) dengan net profit margin (NPM) dengan nilai 95,6\% Korelasi dua variabel tersebut signifikan karena memiliki nilai probabilitas sebesar 0,000 $(<0,025)(b)$ Terdapat korelasi negatif yang sangat kuat antara cost efficiency ratio (CER) dengan net profit margin (NPM) dengan nilai 92,7\%. Korelasi 
duavariabel tersebut signifikan karena memiliki nilai probabilitas sebesar $0,000(<0,025)$.

\section{Hasil Uji Koefisien Determinasi $\left(R^{2}\right)$}

Koefisien determinasi $\left(\mathrm{R}^{2}\right)$ digunakan untuk mengukur seberapa jauh kemampuan model dalam menerangkan variasi pada variabel terikat. Nilai R square terletak antara nol dan satu. Jika nilai $\mathrm{R}$ square mendekati nol, maka kemampuan variabel bebas dalam menjelaskan perubahan pada variabel terikat sangat lemah, sedang kan nilai $\mathrm{R}$ square yang mendekati satu menunjukkan kuatnya pengaruh variabel bebas dalam menentukan segala perubahan yang terjadi pada variabel terikat (Santoso,2010). Hasil uji koefisien determinasi ( $\mathrm{R}$ square) tabel berikut:

Tabel 3

Hasil Uji Koefisien Determinasi $\left(\mathbf{R}^{2}\right)$ ModelSummary ${ }^{\mathrm{b}}$

\begin{tabular}{|r|r|r|r|r|}
\hline Model 1 & R & RSquare & $\begin{array}{c}\text { AdjustedR } \\
\text { Square }\end{array}$ & $\begin{array}{c}\text { Std.Errorofthe } \\
\text { Estimate }\end{array}$ \\
\hline & .957 & .916 & .882 & 2.86784 \\
\hline
\end{tabular}

a. Predictors:(Constant),CER,OER(BOPO)

b. DependentVariabel:NPM

Sumber:DataStatistikOlahan(2018)

Tabel 4 menunjukkan bahwa nilai Koefisien Determinasi $\left(\mathrm{R}^{2}\right)$ dalam penelitian ini adalah 0,916 (mendekati satu). Artinya, operational efficiency ratio (rasio BOPO) dan cost efficiency ratio (CER) sebagai variabel bebas memiliki pengaruh sebesar $91,6 \%$ atas setiap perubahan yang terjadi pada variabel terikat, yakni net profit margin (NPM), sedangkan sisanya sebesar 8,4\% disebabkan oleh hal-hal laindi luar variabel penelitian. 


\section{Hasil Pengujian Hipotesis}

\section{a. Hasil Uji Simultan (Uji F)}

Uji F dilakukan untuk melihat pengaruh dari variabel bebas secara bersama-sama (simultan) terhadap variabel terikat. Dalam hal ini, pengaruh antara operational efficiency ratio (rasio BOPO) dan cost efficiency ratio (CER) secara simultan terhadap net profit margin (NPM). Hasil uji simultan (Uji F) tabel berikut:

Tabel 4 Hasil Uji F ANOVA ${ }^{b}$

\begin{tabular}{|c|c|c|c|c|c|c|}
\hline \multicolumn{2}{|c|}{ Model } & \multirow{2}{*}{$\begin{array}{c}\text { SumofSquares } \\
446.999\end{array}$} & $\mathrm{df}$ & \multirow{2}{*}{$\begin{array}{c}\text { MeanSquare } \\
223.499\end{array}$} & \multirow{2}{*}{\begin{tabular}{|c|}
$F$ \\
27.175
\end{tabular}} & \multirow{2}{*}{$\begin{array}{r}\text { Sig. } \\
.002^{\mathrm{a}}\end{array}$} \\
\hline 1 & Regression & & 2 & & & \\
\hline & Residual & 41.123 & 5 & 8.225 & & \\
\hline & Total & 488.121 & 7 & & & \\
\hline
\end{tabular}

a.Predictors:(Constant),CER,OER(BOPO)

b. DependentVariable:NPM

Sumber: Data Statistik Olahan (2018)

Hasil olah data SPSS pada tabel 5 menunjukan nilai Fhitung $=27,175$, sehingga diperoleh hasil Fhitung 27,175 > Ftabel 4,07. Dan dengan tingkat signifikansi $(\alpha)$ sebesar 0,002 (di bawah 0,05), dapat disimpulkan bahwa operational efficiency ratio (rasio BOPO) dan cost effciciency ratio (CER) secara bersama-sama/serentak berpengaruh signifikan terhadap net profit margin (NPM) dan layak digunakan dalam mode lregresi untuk memprediksi NPM. Maka dari itu, H1 diterima dan H0 ditolak. Dengan demikian, hipotesis yang diajukan diterima berdasarkan hasil uji $\mathrm{F}$ ini.

\section{b. Uji Parsial (Uji t)}

Hubungan secara parsial ini dapat ditinjau dari nilai signifikansi, nilai thitung dan persamaan regresi linear berganda. 
Tabel 5 Hasil Uji t

Coeffecient $^{\mathrm{a}}$

\begin{tabular}{|l|r|r|r|r|r|}
\hline \multirow{2}{*}{ Model } & \multicolumn{2}{|c|}{ UnstandardizedCoefficient } & $\begin{array}{r}\text { Standardized } \\
\text { Coefficienct }\end{array}$ & \multirow{2}{*}{$\mathrm{T}$} & \multirow{2}{*}{ Sig. } \\
\cline { 2 - 4 } & \multicolumn{1}{|c|}{$\mathrm{B}$} & \multicolumn{1}{|c|}{ Std.Error } & \multicolumn{1}{c|}{ Beta } & & \\
\hline 1. Constant & 128.44 & 28.803 & & 4.460 & .007 \\
OER(BOPO) & 9 & .759 & -1.088 & - & .125 \\
CER & - & .507 & .135 & 1.842 & .828 \\
\hline
\end{tabular}

a. DependentVariabel:NPM

Sumber: Data Sekunder Olahan (2018)

Berdasarkan hasil uji t (parsial) seperti yang ditunjukkan pada tabel 7dapat disusun persamaan regresi linear berganda seperti berikut ini:

\section{NPM=128,449- 1,398OER(BOPO)+0,116CER}

Berdasarkan tabel 7 dan persamaan regresi diatas dapat dinterpretasikan beberapa sebagai berikut (1) Operational efficiency ratio (Rasio BOPO) memiliki nilai signifikansi sebesar 0,125 $(>0,05)$ dengan nilai $t$ hitung $\quad(-1.842)<$ ttabel $(2,015)$. Oleh karena itu, operational efficiency ratio( rasio $\mathrm{BOPO})$, sebagai variabel $\mathrm{X}_{1}$ dalam penelitian ini, secara parsial tidak memiliki pengaruh yang signifikan terhadap net profit margin (NPM).

Nilai B yang sebesar-1,398 menunjukkan bahwa setiap terjadi kenaikan pada rasio BOPO sebesar 1\%, maka nilai NPM akan berkurang sebesar1,398\%. (2)Cost efficiency ratio (CER) memiliki nilai signifikasi sebesar 0,828 $(>0,05)$ dengan nilai t hitung $0,228<$ ttabel2,015. Oleh karena itu, CER sebagai variabel $X_{2}$ dalam penelitian ini, secara parsial tidak memiliki pengaruh yangsignifikan terhadap net profit margin (NPM). Nilai B yang sebesar 0,116 menunjukkan bahwa setiap terjadi kenaikan pada CER sebesar 1\%, maka nilai NPM justru bertambah sebesar $0,116 \%$.

Hal tersebut sejalan dengan hasilpenelitian Hays dkk (2010) dimana cost efficiency ratio memiliki pengaruh positif terhadap net profit margin (3) Net profit margin (NPM), sebagai variabel terikat, akan memiliki nilai tetap 
sebesar $128,449 \%$ seandainya operational efficiency ratio (rasio BOPO) dan costefficiency ratio (CER) tidak ada.

Berdasarkan hasil uji parsialdiatas sebenarnya telah didapatkan variabel bebas mana yang memiliki dominasi yangkuat. Hal tersebut didasarkan atas seberapa besar perubahan pada variabel terikat yang disebabkan oleh variabel-variabel bebas. Dan dari hasil uji parsial pada penelitian ini diketahui bahwa variabel $\mathrm{X}_{1},(\mathrm{OER} / \mathrm{BOPO})$ mampu mengubah variabel bebas, NPM sebesar 1,398\% sedangkan variabel $X_{2}$, CER hanya mampu mengubah NPM sebesar $0,116 \%$. Dengan demikian, variabel $\mathrm{X}_{1}$ atau operational efficiency ratio (rasio BOPO) adalah variabel bebas yang memiliki pengaruh paling dominan dalam menentukan NPM.

Hasil uji parsial diatas belum menunjukkan ketepatan yang akurat dalam menentukan variabel bebas mana yang dominan, hal tersebut disebabkan oleh tingkat signifikansi kedua variabel bebas yang masih berada diatas 0,05 (5\%). Belum signifikannya hasil uji t (parsial) penelitian ini dapat disebabkan oleh perubahan angka yang ekstrim, seperti yang terjadi pada tahun 2009, dan perubahan nilai variabel bebas yang serupa.

Maka dari itu, untuk membuktikan variabel bebas mana yang paling mendominasi dengan tingkat ketepatan yang akurat, penulis mengadakan pengujian parsial dengan metode stepwise, yakni dengan cara mencari variabel bebas yang memiliki dominasi yang kuat dan mengeluarkan variabel bebas yang memiliki dominasi yang lemah secara parsial.

Dari motode stepwise diperoleh hasil uji t sebagai berikut : 


\section{Tabel 6}

\section{Hasil Uji t (Metode Stepwise)}

Coeffecient $^{\text {a }}$

\begin{tabular}{|c|c|c|r|r|r|}
\hline \multirow{2}{*}{ Model } & \multicolumn{2}{|c|}{ UnstandardizedCoefficient } & $\begin{array}{c}\text { Standardized } \\
\text { Coefficienct }\end{array}$ & \multirow{2}{*}{ T } & \multirow{2}{*}{ Sig. } \\
\cline { 2 - 3 } & $\mathrm{B}$ & Std.Error & Beta & & \\
\hline 1. Constant & 122.871 & 14.000 & & 8.771 & .000 \\
OER(BOPO) & -1.229 & .153 & -.956 & -8.030 & .000 \\
\hline
\end{tabular}

Sumber:Data Sekunder Olahan (2018)

Berdasarkan hasil uji $\mathrm{t}$ dalam metode stepwise.operational efficiency ratio sebagai variabel bebas yang paling berpengaruh dan dominan terhadap NPM sebagai variabel terikat. Nilai signifikansi sebesar 0,000 $(<0,05)$.

\section{KESIMPULAN}

a. Operational efficiency ratio (Rasio BOPO) dan cost efficiency ratio (CER) memiliki pengaruh sebesar $91,6 \%$ dalam menjelaskan setiap perubahan nilai net profit margin (NPM) antara tahun 2016 dan 2017, sedangkan sisanya sebesar $8,4 \%$ dijelaskan oleh variabel- variabel lain diluar model penelitian.

b. Secara simultan, operational efficiency ratio (rasio BOPO) dan cost efficiency ratio (CER) berpengaruh signifikan terhadap net profit margin (NPM) sesuai dengan hasil temuan pada Uji F. Hasil Uji simultan ini dapat memperkuat alasan bahwa penurunan nilai NPM secara ekstrim pada tahun2009 diBank Mandiri, Tbk disebabkan oleh membengkaknya nilai OER (rasio BOPO) dan CER secara serentak pada tahun yang sama.

c. Secara parsial, operational efficiency ratio (rasio BOPO) berpengaruh negatif, namun cost efficiency ratio (CER) ternyata memiliki pengaruh positif. Bank Mendiri, Tbk perkembangan total biaya non bunga, yang menjadi indikator CER, ternyata dapat mendongkrak total penjualan 
yang menjadi indikator NPM, khususnya pada tahun 2017, dimana terjadi peningkatan total penjualan disaat bank itu sedang merugi. Dan di antara dua variabel bebas tersebut, variabel $\mathrm{X}_{1}$, operational efficiency ratio (rasio $\mathrm{BOPO}$ ) yang berpengaruh dominan secara parsial terhadap variabel terikat, yakni net profit margin (NPM).

\section{DAFTAR PUSTAKA}

Arbi, M. Syarif. 2013. Mengenal Bank dan Lembaga Keuangan Non-Bank. Djambatan.Jakarta

Abdullah, Faisal. 2013. Manajemen Perbankan (Teknik Analisis Kinerja Keuangan Bank). UMM. Malang

Bank Indonesia. 2016. Laporan Perekonomian Indonesia

http://www.docstoc.com/docs/Bank-Performance-Measures diakses 13

Pebruari 2017

http://www.ibsintelligence.com diakses 13 Pebruari 2017

Ikatan Akuntan Indonesia .2014. Standar Akuntansi Keuangan. Penerbit Salemba Empat.Jakarta.

Kohn, Meir. 1993. Money, Banking \& Financial Markets. Elm Street Publishing Services, Inc. $2^{\text {nd }}$ edition. Florida.

Koch, Timothy W., dan S.Scott MacDonald. 2011. BankManagement. Hartcourt College Publishers. $4^{\text {th }}$ edition. Orlando.

Laporan Tahunan Bank Indonesia. 2012\& 2017 (http://www.bi.go.id/), diakses 11 Pebruari 2018

Laporan Tahunan Bank Mandiri, Tbk. 2012 \& 2017 dipublikasikan.

Muljono, Teguh Pudjo. 1999. Analisa LaporanKeuangan untuk Perbankan.Penerbit Djambatan.Jakarta

Saunders, Anthony. 2000. Financial Institution Management: A Modern Perspective. The McGraw-Hill Companies,Inc. $3^{\text {rd }}$ edition.USA.

Santoso, Singgit. 2014. Mastering SPSS 25. Penerbit PT Elex Media Komputindo. Jakarta.

Shao, Stephen Pinyee. 1990. Mathematic forManagement and Finance. SouthWestwern Publishing Co. $6^{\text {th }}$ edition. Ohio. 